\title{
APPLICATION OF PROBIOTIC BACTERIA: A NOVEL APPROACH TOWARDS ENSURING FOOD SAFETY IN SHRIMP AQUACULTURE
}

\author{
SHAFIQUR RAHMAN ${ }^{1}$, SHAKILA N. KHAN ${ }^{1}$, M. NIAMUL NASER ${ }^{2}$ AND M. \\ MANJURUL KARIM ${ }^{1}$ \\ Department of Microbiology ${ }^{1}$ and Department of Zoology ${ }^{2}$; Faculty of Biological \\ Sciences, University of Dhaka, Dhaka 1000, Bangladesh
}

\begin{abstract}
Shrimp export is the second largest exportable commodity in Bangladesh. However, frequent outbreaks of microbial diseases over the last few years challenged its prospect to flourish. The use of antimicrobial chemicals have led to the emergence of more virulent pathogens, with the eventual transfer of antimicrobial resistance to human pathogens. The use of beneficial bacteria (probiotics) to displace pathogens by competitive processes and to inhibit their proliferation is a better remedy than administering antibiotics. A good number of bacteria from rearing environment for shrimp aquaculture with potential probiotic activity in vitro have been isolated. Two approaches, the well diffusion method and co-culture experiments confirmed their probiotic nature. Their non-hemolytic property also ensured their safe mode for application in shrimp aquaculture. Once the effect is successfully translated in the culture ponds, this will be an eco-friendly, harmless approach to combat the disaster caused by bacterial infections without compromising the shrimp quality, thereby ensuring food safety in shrimp industries of Bangladesh.
\end{abstract}

Key words: Probiotic bacteria, food safety, shrimp aquaculture, vibrios

Running title: Probiotic bacteria for shrimp aquaculture

\section{INTRODUCTION}

The total fish production in world market was estimated 110 million tones in 2006, of which the aquaculture accounted for $47 \% .^{(1)}$ In much of the Asian aquaculture, the shrimp culture industry is beset by diseases, mostly due to bacteria (especially the luminous Vibrio harveyi) and viruses. The high density of shrimps in hatchery tanks and rearing ponds is conducive to the spread of pathogens; and the aquatic environment, with regular applications of protein-rich feed, is ideal for bacterial propagation. Although vaccines are being developed and marketed, they generally cannot be used as a universal disease control measure in aquaculture. Juvenile fish are not fully immunocompetent and do not always respond to vaccination. Vaccination by injection, is impractical when applied to small fish or large number of fishes. The addition of substantial amounts of antibiotics and chemotherapeutics remains the method of choice for disease control. This has increased a concern about antibiotic-resistant microorganisms ${ }^{(2)}$ and has led to several alternative suggestions for disease prevention, including the use of nonpathogenic bacteria as probiotic biocontrol agents. ${ }^{(3-6)}$ These so-called beneficial bacteria are not therapeutic agents but will alter directly or indirectly the composition of the microbial community in the rearing environment and in the shrimp gut ${ }^{(7)}$ once applied to the rearing tanks and ponds directly or with the feed respectively. ${ }^{(8)}$ Several reviews detail the various developments made in the use of probiotics in aquaculture species, including shrimp. ${ }^{(9-11)}$ The range of probiotics examined for use in aquaculture encompasses both Gram negative and Gram positive bacteria, bacteriophages, yeasts and unicellular algae. ${ }^{(11)}$ A Pseudomonas sp, for example, isolated from a brackish water lagoon showed significant probiotic activity against a number of shrimp pathogenic vibrios, while its safety in a mammalian system was also found satisfactory. ${ }^{(12)}$ The losses of shrimp production due to luminous vibriosis were found catastrophic and could not be controlled even after use of antibiotics. The use of probiotic bacteria afterwards produced no disease and the shrimp survival was recorded satisfactory. ${ }^{(13)}$ 
Isolation of suitable probiotic bacteria from natural sources, optimization of its antagonistic activity and finally, application in an effective dose in the rearing environment is expected to prevent the growth of undesirable pathogenic microorganisms to proliferate. In the present communication, we report the isolation of a good number of putative probionts from natural sources which demonstrate their antagonism activities against Vibrio spp isolated from Penaeus monodon culture hatcheries and grow-out systems.

\section{MATERIALS AND METHODS}

\section{Target pathogen}

Seventeen water samples were collected aseptically in sterile vials from shrimp culture ponds from Teknaf and Cox's Bazar regions. These were transferred in ice-cold condition to the laboratory and were analyzed for heterotrophic bacterial count on Luria-Bertani (LB) agar media. Twenty one colonies of Vibrio spp were isolated from the samples and identified as Vibrio species by growing on thiosulphate citrate bile salts sucrose (TCBS) agar medium (Oxoid) followed by biochemical analyses. Six isolates were used as target organisms, against which the probiotic bacteria were screened for antagonistic activity.

\section{Putative probionts}

$100 \mu 1$ sampled water was plated on different culture media viz. nutrient agar, trypticase soy agar, basal agar and cetrimide agar media, each supplemented with $1.5 \% \mathrm{NaCl}$, by spread plate method. A total of eighty seven colonies were isolated following incubation at $30^{\circ} \mathrm{C}$ for 24 hours. These were selected for screening after sub-culturing, as no colony was found around their growth on the respective culture media.

\section{Antagonism assay}

Two methods were carried out to evaluate the antagonistic activity of the prospective probionts: the well diffusion assay on solid medium ${ }^{(12)}$ and the co-culture method in culture broth ${ }^{(14)}$. In the well diffusion assay, isolated colonies of candidate probiotic cultures were inoculated in $5 \mathrm{ml} \mathrm{LB}$ broth and grown at $30^{\circ} \mathrm{C}$ on a shaking incubator at $150 \mathrm{rpm}$ for $72 \mathrm{~h}$, and cells were removed by centrifugation at $8,000 \mathrm{~g}$ for $5 \mathrm{~min}$ and the culture supernatant were sterilized by passage through $0.45 \mu \mathrm{m}$ pore size filters (Millipore). Isolated colony of Vibrio sp was precultured in LB broth, incubated at $30^{\circ} \mathrm{C}$ for two days and the culture was swabbed over the Mueller-Hinton agar plates. Wells, 4 $\mathrm{mm}$ in diameter, were punched into the same medium and $80 \mu \mathrm{l}$ of culture supernatants from the candidate probionts were added. The plates were then incubated at $30^{\circ} \mathrm{C}$ for 24 h. Antibacterial activity was estimated as the diameter $(\mathrm{mm})$ of the clear inhibitory zone formed around the discs.

The co-culture method was performed to observe the antagonistic potential of the probionts when grown with the target pathogen concurrently. ${ }^{(14)}$ For this purpose, a population of $10^{3}$ cells, each from the culture broth of the prospective probiont and the target organism were inoculated into LB broth to produce mixed culture. The co-cultures, made in duplicates were incubated at $30^{\circ} \mathrm{C}$ and samples were withdrawn daily up to two days for the enumeration of vibrio count on TCBS media.

\section{Pathogenicity test}

The prospective probionts was cultured by streaking on blood agar media (Oxoid) supplemented with $1.5 \% \mathrm{NaCl}$ in order to evaluate their possible hemolytic activity to be determined by the production of zone of hemolysis around their growth. 


\section{RESULTS}

\section{Isolation of probiotic organism}

The twenty one different Vibrio spp were isolated and identified. Six of them were used as target organisms, of them two were identified as $V$. harveyi and $V$. parahaemolyticus following biochemical analyses (personal communication). Eighty seven colonies, isolated from the rearing environment of shrimp aquaculture me, were primarily selected as probionts for evaluating possible antagonistic activities against the target pathogens.

\section{Antagonism assay result}

The well-diffusion assay, where the cell-free supernatants of 3-day old cultures of candidate probionts were added in pre-formed wells, dug in Mueller-Hinton agar media and previously swabbed with target pathogens, revealed that a good number of probionts challenged the pathogens successfully as evidenced by the production of clear zones of inhibition against the growth of the target pathogens (Fig. 1). The figure includes only those candidates that produced $>10 \mathrm{~mm}$ inhibitory zones against a two-day old culture. Probionts isolated from Basal medium that selects the growth of Bacillus were found most efficient against vibrios as they yielded 20-30 $\mathrm{mm}$ zones of inhibition.

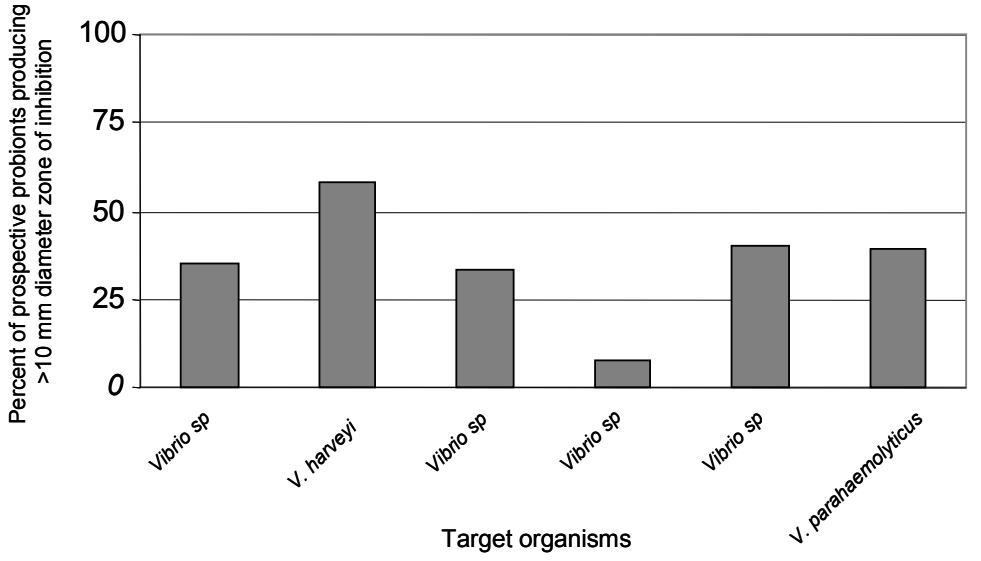

Fig. 1. Antagonism assay. The result of antagonism assay from well-diffusion method presents the numbers of prospective probionts out of eighty seven candidates (in percentage) that produced clear zones of inhibition of at least $10 \mathrm{~mm}$ in diameter against a two-day old Vibrio culture.

In the co-culture experiment, equal number $\left(10^{3}\right.$ cells $)$ of bacterial population (i.e. the prospective probiont and $V$. proteolyticus used as the target organism) was inoculated into LB broth to produce mixed culture. A two-day time-course experiment revealed two trends of vibrio growth as enumerated on TCBS agar media. The first trend clearly produced vibriocidal activity within two days of co-cultivation with a good number of probionts; while the other trend showed an inverse order when inoculated with some other prospective probionts (Fig. 2). This in turn indicates variability of different probionts' effect against a particular organism. 


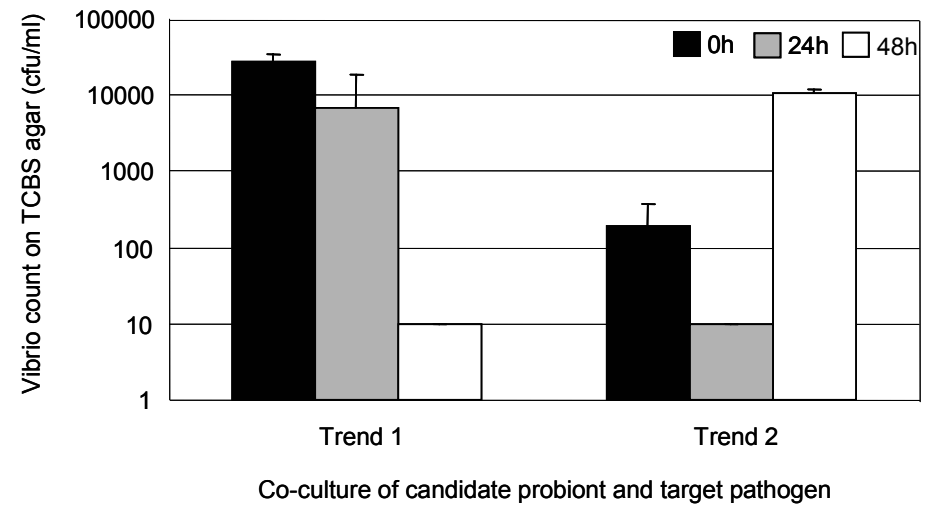

Fig. 2: Co-culture experiment. Effect of vibrio growth, the target pathogen is shown in combinations of equal numbers of different probiotic bacteria over the two days of cultivation.

\section{Pathogenicity test result}

The antagonism assays short listed thirty seven isolates of prospective probionts which were subjected to pathogenicity test to study their ability to hemolyze sheep red blood cells on blood agar. This is a preliminary approach to address whether they are safe to mammalian system. Nineteen of them produced no hemolysis, as revealed by their inability to produce hemolytic zones on the medium (Fig. 3).
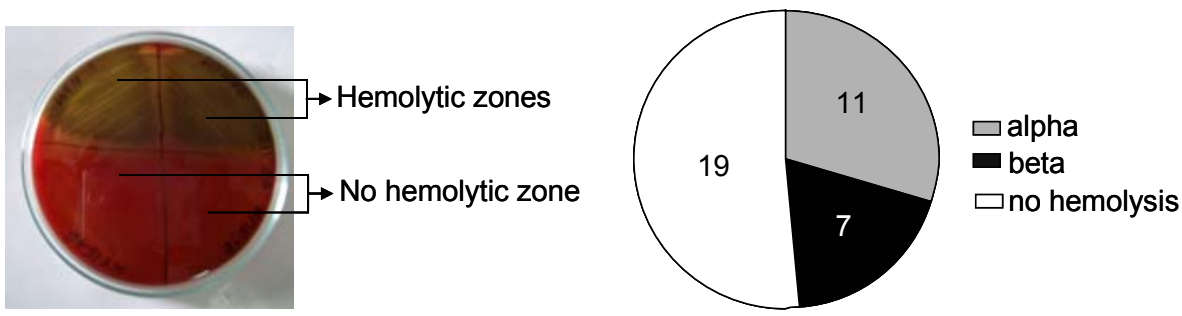

Fig. 3. Hemolytic activity. The pie graph shows the number of candidate probionts having hemolytic property. A typical plate shows formation of hemolytic zones following growth of the candidate probionts on blood agar.

\section{DISCUSSION}

When diseases are detected, hatchery technicians and in some cases farmers apply antibiotics as prophylactics in large quantities, even when pathogens are not evident. This has led to an increase in Vibrios, and presumably other bacteria, having multiple antibiotic resistance patterns. Many of the pathogens appear to have mutated to more virulent forms than were present a decade ago, and thus even when the shrimps are not stressed by poor water quality they succumb to attack. Thus, it is assumed that the incidence of disease has been exacerbated by the actions of the hatchery operators or shrimp farmers. If antibiotics or disinfectants are used to kill bacteria, some bacteria will survive. These will then grow rapidly because their competitors are removed. Any 
virulent pathogens that re-enter the pond or hatchery tank, perhaps from within biofilms in water pipes or in the guts of animals, can then exchange genes with the resistant bacteria and survive further doses of antibiotic. Thus, antibiotic-resistant strains of pathogens evolve rapidly.

The available literature shows that it is possible to change bacterial species composition in large water bodies, hatchery tanks and prawn guts and improve prawn production. ${ }^{(8)}$ Vibrio species can be controlled in this manner. The control of virus disease is possible, but is more complex than controlling pathogenic bacteria. Fish and shrimp farmers who manage the microbial ecology of their ponds by suitable application of probiotic bacteria are succeeding in the presence of white spot virus and Vibrio. In fact, the field of probiosis has emerged as a new science with applications in farming and aquaculture as alternatives to antibiotics. ${ }^{(8)}$

The development of suitable probiotics requires empirical and fundamental research, full scale trials, as well as the development of appropriate monitoring tools. To our knowledge, no study had been conducted in Bangladesh. On controlling bacterial infection in shrimps on farms in relation to probiotic usage. It may be mentioned that a good number of probiotics, of foreign origin were tested in some hatcheries and culture ponds of Khulna region and was not found to be effective (personal communication). This observation demands to discover new probiotics from the indigenous origin to be effective in local environment.

The present study showed that the growth of some selected Vibrio spp can be controlled by a good number of bacteria after screening eighty seven isolates collected from the indigenous environment. They exhibit zones of clearance against pathogenic vibrios on diffusion agar plates (Figure 1). It may be mentioned that most of the prospective probionts appeared to be effective against $V$. harveyi, the agent responsible for causing luminous vibriosis. The results of well diffusion indicate that it is not the bacterial cell but an extracellular product that is likely to be responsible for inhibition, and the extent of inhibition varies depending on target pathogens.

Our second attempt for antagonism study produced two different trends of growth inhibition against $V$. parahaemolyticus. While a group of candidate probionts produced vibriocidal activity in the next two days, another group failed to produce the same in a 1:1 bacterial population of probiont and pathogen (Figure 2). The activity of the latter group is now required to be further tested by applying greater number of probionts. Such an approach would also enable one to understand whether the release of antibacterial metabolites by probiotic bacteria is an inductive or constitutive phenomenon in presence of pathogenic counterparts. The non-hemolytic nature of the nineteen candidate probionts indicates that they would not be fatal for mammalian host if entered into the food chain (Figure 3). This is an important consideration as far as the food safety is concerned. These nineteen isolates, which also produced antagonistic potential, will be further characterized for their pathogenicity, if present, by testing in the brine shrimp and brood stock subsequently.

Probiotic treatment offers a promising alternative to the antibiotics for fish and shrimp aquaculture system. Since probiotics are made from natural mechanisms, shrimp farmers who learn to farm microorganisms will be far more likely to achieve successful harvests. Hence, the hunt for suitable probiotics from natural environment will ensure healthy environment for rearing aquaculture on one hand, and food safety in shrimp industries on the other. 


\section{ACKNOWLEDGEMENTS}

The financial support of Biotechnology Research Centre of the University of Dhaka, Dhaka, Bangladesh in conducting the study is gratefully acknowledged.

\section{REFERENCES}

1. FAO. The State of World Fisheries and Aquaculture, Food and Agriculture Organization (FAO), Rome, Italy, pp 175, 2009.

2. Ama'Bile-Cuevas, C.F., Ga'rdenas-Garcia', M. and Ludgar, M. Antibiotic resistance. Am. Sci. 83, 320-329, 1995.

3. Austin, B. Stuckey, L. F. Robertson, P. A. W. Effendi, I. and Griffith, D. R. W. A probiotic strain of Vibrio alginolyticus effective in reducing diseases caused by Aeromonas salmonicida, Vibrio anguillarum and Vibrio ordalii. J. Fish Dis. 18, 93-96, 1995.

4. Bly, J. E. Quiniou, S. M.-A. Lawson, L. A. and Clem. L. W. Inhibition of Saprolegnia pathogenic for fish by Pseudomonas fluorescens. J. Fish Dis. 20, 35-40, 1997.

5. Smith, P. and S. Davey. Evidence for the competitive exclusion of Aeromonas salmonicida from fish with stress-inducible furunculosis by a fluorescent pseudomonad. J. Fish Dis. 16, 521-524, 1993

6. Westerdahl, A. Olsson, J. C. KJelleberg, S. and Conway, P. L. Isolation and characterization of turbot (Scophthalmus maximus)-associated bacteria with inhibitory effects against Vibrio anguillarum. Appl. Environ. Microbiol. 57, 2223-2228, 1991.

7. Vershuere, L. Rombaut, G. Sorgeloos, P. Verstraete, W. Probiotic bacteria as biological control agents in aquaculture. Microbiol. Mol. Biol. Rev. 64, 655-671, 2000.

8. MoriarTy, D.J.W. Disease Control in Shrimp Aquaculture with Probiotic Bacteria In Microbial Biosystems: New Frontiers. Proceedings of the 8th International Symposium on Microbial Ecology, Bell, C.R. Brylinsky, M. Johnson-Green, P. (eds) Atlantic Canada Society for Microbial Ecology, Halifax, Canada, pp. 237-243, 1999.

9. Garriques, D. Arevalo, G. An evaluation of the production and use of a live bacterial isolate to manipulate the microbial flora in the commercial production of Penaeus vannamei postlarvae in Ecuador. In: BRowdy, C. L. Hopkins, J. S. (eds.), Swimming through Troubled Water. Proceedings of the Special Session on Shrimp Farming, Aquaculture '95. World Aquaculture Society, Baton Rouge, LA, pp. 53-59, 1995.

10. Gatesoupe, F. J. The use of probiotics in aquaculture. Aquaculture 180, 147-165, 1999.

11. Irianto, A. Austin, B. Review probiotics in aquaculture. J. Fish Dis. 25, 633, 2002.

12. Vijayan, K. K. Bright Singh, I. S. Jayaprakash, N. S. Alavandi, S. V. Somnath Pai, S. Preetha, R. Rajan, J. J. S. SANTiago, T. C. A brackishwater isolate of Pseudomonas PS-102, a potential antagonistic bacterium against pathogenic vibrios in penaeid and non-penaeid rearing systems. Aquaculture 251, 192-200, 2006.

13. Moriarty, D. J. W. Control of luminous Vibrio species in penaeid aquaculture ponds Aquaculture 164, 351-358, 1998.

14. Vaseeharan, B. Ramasamy, P. Control of pathogenic Vibrio spp. by Bacillus subtilis BT23, a possible probiotic treatment for black tiger shrimp Penaeus monodon. Lett. Appl. Microbiol. 36, 83-87, 2003.

Journal of Bangladesh Academy of Sciences, Vol. 33, No. 1, 139-144, 2009 